\title{
The influence of demographic variables on service quality perceptions in three selected service industries
}

\author{
Christo Boshoff \\ Department of Business Economics, Vista University, Private Bag X613, Pon Elizabeth 6000, Republic of South Africa \\ Deon Nel \\ Department of Business Management, Rand Afrikaans University, P.0. Box 524, Auckland Park 2006, Republic of South Africa
}

\author{
Received 7 October 1991, accepted 31 August 1992
}

\begin{abstract}
Despite reservations about the use of demographic variables for market segmentation purposes it is a method which is widely used. Although this was not a segmentation study as such, the extent to which service quality perceptions are influenced by demographic variables has been investigated. It is believed that if demographic variables are found to influence service quality perceptions, they may serve as important pointers to the marketers of services when considering segmentation strategies. The empirical results revealed that both age $(p<0.05)$ and level of education $(p<0.01)$ exert a significant influence on consumers' perceptions of service quality. Younger consumers and relatively well-qualified consumers rate service quality lower than do older consumers and consumers who are not particularly well qualified academically. Both younger and well qualified consumers could be important target markets to services marketers in delivering quality service.
\end{abstract}

\begin{abstract}
Alhoewel voorbehoude al uitgespreek is oor die gebruik van demografiese veranderlikes as segmenteringsbasis, is dit 'n metode wat wye aanvaarding geniet. Hierdie was nie 'n segmentasiestudie as sodanig nie, maar het die invloed van demografiese veranderlikes op verbruikers se persepsies van diensgehalte ondersoek. Die uitgangspunt was dat indien demografiese veranderlikes wel persepsies van diensgehalte beïnvloed, die bevindinge belangrike aanwysers vir die bemarkers van dienste kan wees, by the formulering van segmenteringstrategieë. Die empiriese bevindinge toon dat beide ouderdom $(p<0.05)$ en opvoedingsvlak $(p<0.01)$ 'n beduidende invloed op verbruikers se persepsies van diensgehalte uitoefen. Jonger verbruikers en relatief goed gekwalifiseerde verbruikers evalueer beide diensgehalte laer as ouer en swakker gekwalifiseerde verbruikers. Beide jonger en goed gekwalifiseerde verbruikers kan belangrike teikenmarkte wees vir die bemarkers van dienste in the lewering van gehalte diens.
\end{abstract}

\section{Introduction}

Traditional marketing wisdom (the marketing concept) holds that knowledge of consumer needs is central not only to satisfying those needs but also to the eventual survival and prosperity of the firm. More specifically, the needs and perceptions of consumers are of particular concern to the marketing manager who can use this information to structure an effective market segmentation strategy. The segmentation strategy will in turn have a key influence on the targeting strategy, the positioning strategy, and, eventually, the entire marketing strategy.

A market can typically be segmented according to a number of different variables. One of these is demographic. In this study, an attempt is made to establish whether demographic variables exert an influence on service quality perceptions in three selected service industries. If demographic variables are found to influence service quality perceptions, such a finding could serve as an important pointer to services marketers in the use of market segmentation strategies.

\section{Market segmentation}

The fact that markets are not homogeneous has been accepted by marketers. Whilst heterogeneity may be problematic to some marketers, it is an opportunity for the consumer-oriented firm to fine-tune its products and services to specific market segments (Frank, Massy \& Wind 1972: 5). The rationale behind such 'customization' of the product or service is that improved customer satisfaction will ensure repeat purchases, customer loyalty, and, eventually, improved profits. In the long term, it is likely to lead to the survival and growth of the firm.

\section{Demographics as a market segmentation variable}

Markets can be segmented on the basis of many variables. The various segmentation approaches can be classified into two groups. The first can be described as general customer characteristic segmentation variables which include demographic variables, socio-economic factors and personality traits. The second group comprises situation-specific variables such as consumption patterns and perceptions, which include behaviour segmentation, usage, purchase $\alpha$ casion, benefits sought, user status and attitude towards the product. Of these two approaches, demographics is the most frequently used (Kotler, 1988).

Some researchers have questioned the usefulness of demographic segmentation. The research findings reviewed by Frank et al. (1972) do not provide a clear-cut answer. Studies analyzing gender as a segmentation variable have reported conflicting evidence. Age for example is described in one study as '... one of the oldest and most acceptable bases for segmentation' (Frank et al., 1972: 32). Frank et al. (1972:61) are of the opinion that the validity of demographics as a segmentation variable depends on:

- the types of products (frequently purchased versus durables);

- the type of dependent variable used;

- the type of independent variable used;

- the unit of analysis (for example family unit); and

- the research procedures utilized.

Much of the work which has cast suspicion on demographics as a viable segmentation variable has been based on frequently purchased household products. It is therefore doubtful if this limited body of knowledge permits generalization 
to other categories of products and in particular, services.

This study reports on the influence of demographics on service quality perceptions. If demographics influence service quality perceptions, it may serve as important pointers to the marketers of services when considering segmentation strategies.

\section{Hypotheses}

The hypotheses addressed in this study are divided into a main hypothesis pertaining to the total sample, and sub-hypotheses which apply to the individual service industries being studied.

The main hypothesis which will be addressed is:

$\mathrm{HO}_{1}$ There is no association between demographic variables and perceived service quality in the three selected service industries.

The following sub-hypotheses were addressed:

$\mathrm{HO}_{1 \wedge}$ There is no association between demographic variables and perceived service quality in the banking industry.

$\mathrm{HO}_{1 \mathrm{~B}}$ There is no association between demographic variables and perceived service quality in the motor repair industry.

$\mathrm{H}_{1 \mathrm{C}}$ There is no association between demographic variables and perceived service quality in the insurance brokerage industry.

\section{Methodology}

Services have been classified along a variety of dimennsions (Lovelock, 1983; Thomas, 1978). Roberts \& Kelley (1985: 285), for instance, distinguish between techno-services and traditional services. The former rely heavily on modern technology and are more capital intensive. Traditional services rely less on the technical component and more on personal service delivery and human interaction. Since retail (nonbusiness) banking, motor vehicle repair and insurance brokerage services have been selected for analysis, traditional services will be the focus of the study. The population has been defined as those who have made use of one of the three services during the preceding twelve-month period.

A combination of judgemental and probability sampling was used to select the respondents for this research. The South African Broadcasting Corporation television mailing list served as the sampling frame. This approach was deemed appropriate since the three selected services are widely used by consumers as opposed to specialized services like architectural services or home decorating services. A systematic random sample was then drawn, following a random start. The total sample size totalled 1950 with an equal proportion of 650 interviews being allocated to each service industry.

Mail interviews, with instructions on their completion were mailed to respondents with a covering letter explaining the purpose of the study. Three weeks later, reminder notices were mailed to all respondents who had not yet returned their questionnaires. Two weeks later a second questionnaire was mailed. In total 459 usable questionnaires were returned, a total response rate of $23.5 \%$. Per individual sub-sample, the response rate was: $27.7 \%$ for banking, $21.7 \%$ for motor repair services and $21.1 \%$ for insurance brokerage services.
Table 1 depicts the nature of the respondent group in demographic terms. Females were relatively well represented in the banking sample of the survey, but to a lesser extent with regard to motor repair services and insurance brokerage services. The distribution of the respondents in the various age categories is roughly the same for all three sub-samples. The same applies for the educational qualifications of the respondents.

\section{Measuring instrument}

The SERVQUAL instrument developed by Parasuraman, Zeithaml \& Berry (1988) was used to measure perceptions of service quality. This questionnaire consists of two sections, an expectations section and a perceptions section. The expectations section requires the respondents to indicate on a Likert-type scale the extent to which the ideal service provider possesses the characteristic described in each statement. In the perceptions section the statements require the respondent to indicate the extent to which the specific company possesses the characteristic described in the statement. Respondents had to indicate their agreement/disagreement with each statement on a 5-point scale ranging from strongly agree (5) to strongly disagree (1). With the data from SERVQUAL, it is possible to quantify the overall service quality gap. Certain classification data werc appended to the questionnaire in order to present service quality scores according to the abovementioned demographical variables (see Table 1).

\section{Emplrical findings}

To consider the influence of demographic variables on service quality perceptions in the three selected service industries, the first step of this investigation was to calculate the SERVQUAL (SQ) scores of the individual service industries by means of difference scores per item. The difference between expectations $(E)$, and the evaluation of actual service delivery perceptions $(P)$ is calculated using the formula $S Q=$ P-E. SERVQUAL scores represent the perceived service quality for that particular item. To determine the SERVQUAL score for a particular service industry, a mean difference score then has to be calculated, considering all 22 expectation items (statements) and the 22 evaluation (or perception) items simultaneously. A SERVQUAL score of zero means that market requirements are perfectly matched, meaning that customers are technically satisfied. A positive SERVQUAL score means that the industry actually performs better than expected by respondents. A negative SERVQUAL score means that perception scores are falling short of customer expectations. Considering that a 5-point scale was used, the theoretical minimum and maximum range of SERVQUAL scores would be between -4 and +4 .

Table 2 shows the SERVQUAL scores for each of the service industries. The insurance brokerage industry returned the most favourable SERVQUAL score of -0.377 . The next best is the banking industry with a SERVQUAL score of -0.493 , followed by the motor repair industry with a SERVQUAL score of -0.560 . Therefore none of the service industries meet customer expectations. The average SERVQUAL score for the three service industries is -0.479 (see Table 2). 
Table 1 Demographics per service industry

\begin{tabular}{|c|c|c|c|c|c|c|}
\hline \multirow[t]{3}{*}{ Demographic variable } & \multicolumn{6}{|c|}{ Service industry } \\
\hline & \multicolumn{2}{|c|}{ Banking } & \multicolumn{2}{|c|}{ Motor repair } & \multicolumn{2}{|c|}{ Brokerage } \\
\hline & No & $\%$ & No & $\%$ & No & $\%$ \\
\hline \multicolumn{7}{|l|}{ Gender } \\
\hline Male & 123 & 68.3 & 108 & 76.6 & 112 & 81.2 \\
\hline \multirow[t]{2}{*}{ Female } & 57 & 31.7 & 33 & 23.4 & 26 & 18.8 \\
\hline & 180 & 100.0 & 141 & 100.0 & 138 & 100.0 \\
\hline \multicolumn{7}{|l|}{ Age } \\
\hline $20-24$ & 5 & 2.8 & 3 & 2.1 & 2 & 1.4 \\
\hline $25-34$ & 41 & 22.8 & 37 & 26.2 & 43 & 31.2 \\
\hline $35-44$ & 46 & 25.5 & 24 & 17.0 & 32 & 23.2 \\
\hline $45-54$ & 30 & 16.7 & 31 & 22.0 & 24 & 17.4 \\
\hline $55-64$ & 34 & 18.9 & 27 & 19.2 & 20 & 14.5 \\
\hline $65-74$ & 17 & 9.4 & 11 & 7.8 & 15 & 10.9 \\
\hline \multirow[t]{2}{*}{$75+$} & 7 & 3.9 & 8 & 5.7 & 2 . & 1.4 \\
\hline & 180 & 100.0 & 141 & 100.0 & 138 & 100.0 \\
\hline
\end{tabular}

Educational qualifications

\begin{tabular}{lcccccc}
\hline Std 9 and lower & 26 & 14.4 & 19 & 13.5 & 16 & 11.6 \\
Std 10 & 53 & 29.4 & 36 & 25.5 & 35 & 25.4 \\
Diploma & 50 & 27.9 & 39 & 27.7 & 28 & 20.3 \\
Degree & 51 & 28.3 & 47 & 33.3 & 59 & 42.8 \\
\hline & 180 & 100.0 & 141 & 100.0 & 138 & 100.0
\end{tabular}

Home language

\begin{tabular}{lrrrrrr}
\hline Afrikaans & 96 & 53.3 & 63 & 44.7 & 85 & 61.6 \\
English & 82 & 45.6 & 74 & 52.5 & 51 & 37.0 \\
European & 2 & 1.1 & 3 & 2.1 & 2 & 1.4 \\
Other & 0 & 0 & 1 & 0.7 & 0 & 0 \\
\hline & 180 & 100.0 & 141 & 100.0 & 138 & 100.0
\end{tabular}

Table 2 SERVQUAL scores per industry

\begin{tabular}{lcccc}
\hline Service industry & SQ score & SD & Min & Max \\
\hline Banking & -0.493 & 0.575 & -2.500 & 1.000 \\
Motor repair & -0.560 & 0.676 & -2.455 & 0.500 \\
Brokerage & -0.377 & 0.546 & -2.727 & 0.545 \\
\hline Average & -0.479 & & & \\
\hline
\end{tabular}

\section{SERVQUAL scores according to demographics}

Multiple regression analyses were used to investigate the possible association between key demographic variables and service quality scores. Regression analysis generally investigates the influence of a set of independent variables on a dependent variable by means of a mathematical model. If more than one independent variable might be responsible for the variation in the dependent variable, a multiple regression analysis is appropriate (Parasuraman, 1986: 664). A multiple regression equation with $k$ independent variables can be written in the following form:

$Y=a+b_{1} X 1+b_{2} X 2+\ldots+b_{k} X k$

where $\mathrm{Y}$ is the dependent variable; $\mathrm{X} 1, \mathrm{X} 2 \ldots \mathrm{Xk}$ are the independent variables; and $b 1, b 2$... bk are the regression coefficients for the corresponding independent variables and $a$ is the $\mathrm{Y}$-intercept.

Demographic variables were used as independent variables to predict service quality perceptions - the dependent variable (SERVQUAL scores). Three multiple regression procedures were performed, with the SERVQUAL score for each industry as dependent variables. A fourth regression was performed using the average SERVQUAL score of the three industries as the dependent variable.

\section{Multiple regression results: Demographics on the average SERVQUAL score of the three industries}

In the first multiple regression analysis, the average SERVQUAL score for the total sample served as the dependent variable, while gender, age, educational qualifications and home language constituted the independent variables. The SAS GLM (SAS Institute 1988) procedure was used to test $\mathrm{HO}_{1}$. The results tabulated in Table 3 reveal that the regression coefficients age and education are the only ones which differ significantly $(p<0.05$ for age and $\mathrm{p}<0.01$ for education) from zero, therefore making a significant contribution towards explaining the variation in the dependent variable. In other words, age and level of education are the only demographic variables which have a significant influence on service quality perceptions, as measured by the SERVQUAL scores of the total sample.

The influence of age is positive, implying the older the respondent the higher the SERVQUAL score. The level of education retumed a negative coefficient. In other words, respondents with a relatively high level of education rate service quality delivery significantly lower than those with lower levels of education. The null hypothesis $\left(\mathrm{HO}_{1}\right)$ is thus rejected with regard to the demographic variables age and education. Service quality perceptions are, however, influenced neither by gender nor the home language of respondents (see Table 3).

\section{Influence of demographic variables on perceived service quality in the banking industry}

The investigation into consumer perceptions of service quality was extended by focussing on each service industry individually. The SERVQUAL score for each service industry served as the dependent variable. In the case of the banking industry, gender, age, educational qualification, home language, the method used to conduct banking business (for example personal visits), the type of services used (for examaple current accounts), served as independent variables. To test the hypothesis $\left(\mathrm{HO}_{1 \mathrm{~A}}\right)$ by means of a multiple regression procedure, the SAS GLM procedure was used (SAS 
Teble 3 The effect of demographic variables on perceived service quality

\begin{tabular}{lrrl}
\hline Independent variables & Coefficient & $t$-value & $P>(t)$ \\
\hline Intercept & -0.604 & -3.36 & 0.0009 \\
Gender & -0.007 & -0.22 & 0.8267 \\
Age & 0.045 & 2.30 & $0.0218^{b}$ \\
Std 9 and lower & 0.110 & 1.72 & 0.0853 \\
Matric & 0.058 & -1.21 & 0.2272 \\
Diploma & $-0 .-39$ & -0.79 & 0.4277 \\
Degree & -0.130 & -2.75 & $0.0062^{*}$ \\
Afrikaans & -0.033 & -0.20 & 0.8407 \\
English & -0.082 & -0.50 & 0.6168 \\
European & 0.119 & 0.26 & 0.7938 \\
\hline
\end{tabular}

a) $p<0.01$

b) $\mathrm{p}<0.05$

Institute 1988). The results reported in Table 4 show a pattern similar to that discemed in Table 3, namely, that age and level of education have a significant influence on perceived service quality in the banking industry.

Again the influence of age is positive, implying the older the respondent the higher the SERVQUAL score. Respondents with higher educational qualifications also differ significantly in their perceptions of service quality from those with lower educational qualifications. The relationship is negative - those with higher qualifications evaluate service quality in the banking industry lower than less well qualified respondents. Because age and educational qualification do influence service quality perceptions in the banking industry, the null hypothesis $\left(\mathrm{HO}_{1 \wedge}\right)$ is rejected with regard to these particular demographic variables. Service quality perceptions in the banking industry are not influenced by gender, home language, the method used by respondents to conduct their

Table 4 The effect of demographic variables on perceived service quality: banking industry

\begin{tabular}{lrrl}
\hline Independent variables & Coefficient & t-value & $P>(t)$ \\
\hline Intercept & -0.687 & -3.42 & 0.0008 \\
Gender & 0.079 & 157 & 0.1196 \\
Age & 0.065 & 1.99 & $0.0488^{b}$ \\
Std 9 and lower & 0.213 & 2.16 & $0.0322^{b}$ \\
Matric & 0.045 & 0.61 & 0.5416 \\
Diploma & -0.056 & -0.73 & 0.4645 \\
Degree & -0.200 & -2.59 & $0.0105^{b}$ \\
Afrikaans & 0.065 & 1.27 & 0.2078 \\
English & -0.065 & -1.27 & 0.2078 \\
European & 0.435 & 1.62 & 0.1077 \\
Auto teller & -0.077 & -1.05 & 0.2961 \\
Personal visit & 0.081 & 1.24 & 0.2168 \\
Savings account & -0.257 & -0.33 & 0.7412 \\
Current account & -0.059 & -0.34 & 0.7326 \\
Credit card & 0.477 & 1.08 & 0.2801 \\
Combination & -0.168 & -1.05 & 0.2946 \\
\hline
\end{tabular}

b) $p<0.05$ banking business and the type of banking services used by respondents (see Table 4).

\section{Influence of demographic variables on perceived service quality in the motor repair service industry}

To test the null hypothesis $\left(\mathrm{HO}_{1 \mathrm{~B}}\right)$, the SERVQUAL score for the motor repair industry was used as the dependent variable while gender, age, educational qualifications, home language and the type of motor repair firm used (franchised dealer versus independent garage) served as independent variables.

The results reported in Table 5 indicate that gender is the only demographic variable which has a significant influence $(p<0.05)$ on perceived service quality in the motor repair service industry. Male respondents rate service quality in the motor repair service industry significantly lower than do females. The null hypothesis $\left(\mathrm{HO}_{1 \mathrm{~B}}\right)$ is thus rejected with regard to gender. Age, educational qualifications, home language, and the type of motor repair firm used have no significant bearing on service quality perceptions in the motor repair service industry (see Table 5).

Influence of demographic variables on perceived service quality in the insurance brokerage industry

A multiple regression analysis was also used to test the hypothesis $\left(\mathrm{H}_{1 \mathrm{c}}\right)$ that there is no association between demographic variables and perceived service quality in the insurance brokerage industry.

The dependent variable was once again the SERVQUAL score for the insurance brokerage industry. Gender, age, educational qualification, home language, the type of services used and whether the services of another broker are used, served as independent variables. The SAS GLM procedure (SAS institute 1988) was used for the analysis, which is tabulated in Table 6. Table 6 shows that level of education is the only demographic variable which has a significant influence on service quality perceptions in the insurance brokerage industry. Again the influence is negative, meaning that respondents with higher educational qualifications rate service quality in the insurance brokerage industry significantly lower than less well educated respondents. The null

Table 5 The effect of demographic variables on perceived service quality: Motor repair industry

\begin{tabular}{lrrl}
\hline Independent variables & Coefficient & t-value & $P>(t)$ \\
\hline Intercept & -0.537 & -2.04 & 0.0435 \\
Gender & -0.173 & -2.49 & $0.0140^{\circ}$ \\
Age & 0.022 & 0.54 & 0.5930 \\
Std 9 and lower & -0.049 & -0.36 & 0.7219 \\
Matric & 0.092 & 0.90 & 0.3705 \\
Diploma & -0.077 & -0.77 & 0.4451 \\
Degree & 0.034 & 0.36 & 0.7187 \\
Afrikaans & -0.038 & -0.18 & 0.8561 \\
English & -0.028 & -0.13 & 0.8945 \\
European & -0.055 & -0.16 & 0.8769 \\
Franchised & -0.091 & -1.54 & 0.1260 \\
Independent & 0.091 & 1.54 & 0.1260 \\
\hline
\end{tabular}

b) p $<0.05$ 
hypothesis $\left(\mathrm{HO}_{1 \mathrm{c}}\right)$ is thus rejected with regard to the demographic variable, education.

Quality perceptions in the insurance brokerage industry are, however, not influenced by the demographic variables gender, age, home language, the type of brokerage services used, or the use of other brokers (see Table 6).

\section{Summary and managerial implications}

This study has dealt with the influence of a number of demographic variables on perceived service quality. The initial analysis involved the three service industries considered collectively, followed by a similar analysis for each service industry individually. The analysis revealed that for the total sample, age and level of education were the only demographic variables which influence service quality perceptions. Younger respondents perceive service quality to be significantly lower than do older respondents. Similarly, better qualified respondents perceive service quality to be lower than those who are not as well qualified. The other demographic variables considered, gender and home language, have no significant influence on service quality perceptions.

When individual service industries were placed under the spotlight, the same set of demographic variables were considered, with the addition of some variables unique to the particular service industry. Perceptions of service quality in the banking industry also appear to be influenced by age and educational qualifications. Younger and better educated respondents rate service quality in the banking industry lower than older and less well educated respondents. Perceived service quality in the banking industry is, however, not influenced by gender, home language, the method used to conduct banking business or the type of banking services used by

Table 6 The effect of demographic variables on perceived service quality: Insurance brokerage industry

\begin{tabular}{lrrl}
\hline Independent variables & Coefficient & t-value & $\mathrm{P}>(\mathrm{t})$ \\
\hline Intercept & 0.596 & -2.53 & 0.0128 \\
Gender & 0.007 & 0.12 & 0.9062 \\
Age & 0.016 & 0.46 & 0.6483 \\
Std 9 and lower & 0.071 & 0.61 & 0.5407 \\
Matric & 0.079 & 0.95 & 0.3450 \\
Diploma & 0.074 & 0.80 & 0.4253 \\
Degree & -0.223 & -2.86 & 0.0049 \\
Afrikaans & 0.195 & 1.37 & 0.1720 \\
English & 0.210 & 1.42 & 0.1568 \\
European & -0.405 & -1.49 & 0.1389 \\
Life assurance & -0.176 & -1.20 & 0.2336 \\
Endowment & 0.328 & 1.53 & 0.1295 \\
Annuity & -0.334 & -1.38 & 0.1711 \\
Unit trust & 0.249 & 0.75 & 0.4536 \\
Other (estate planning etc.) & -0.076 & -0.46 & 0.6459 \\
Combination & 0.009 & 0.08 & 0.9346 \\
Other broker - Yes & -0.039 & -0.77 & 0.4451 \\
Other broker - No & 0.039 & 0.77 & 0.4451 \\
\hline & & & \\
\hline
\end{tabular}

a) $\mathrm{p}<0.01$ respondents. This finding may be of interest to the marketers of banking services. Younger clients rate service quality lower which indicates that younger people are less tolerant of poor service quality delivery. This finding highlights the need for banking executives to monitor service delivery in the younger age categories more carefully.

Better qualified respondents may be relatively more demanding due to higher expectations originating from their superior qualifications and knowledge. Many banks have targeted high-income earners in recent years with specially designed financial packages (for instance Volkskas Bank with its Cum Laude account and First National Bank with its Premier and Status accounts). It is apparent, however, that banks have not succeeded in satisfying the needs of this important market segment in particular.

In the motor repair industry, gender proved to be the only variable which influences service quality perceptions to a significant extent. Males rate motor repair service quality significantly lower than their female counterparts, possibly because they are generally more technically inclined. This could influence higher expectations and lower service quality perceptions regarding motor vehicle repair services. The marketers of motor repair services may therefore need to pay special attention to males, especially if one considers the importance of the role of men in new vehicle purchases and decisions regarding motor vehicle repair in the typical South African family. In addition, motor vehicle fleet managers are also likely to be male, and fleet sales are in the region of $70 \%$ of new vehicle sales in South Africa.

In the insurance brokerage industry, service quality perceptions are influenced by level of education - those who are relatively better qualified academically perceive quality in the brokerage industry to be lower than those who are less well qualified.

\section{Acknowledgement}

The financial assistance provided by the Institute for Research Development of the Human Sciences Research Council is hereby acknowledged. Any opinions expressed and the conclusions reached are those of the authors and should not be attributed to either the Institute for Research Development or the Human Sciences Research Council.

\section{References}

Frank, R.E, Massy, F.W. \& Wind, Y. 1972. Market segmentation. Englewood Cliffs, New Jersey: Prentice-Hall.

Kotler, P. 1988. Marketing management: Analysis, planning, implemensation and control. Sixth edition. Englewood Cliffs, New Jersey: Prentice-Hall.

Lehtinen, U. \& Lehtinen, J.R. 1985. Service quality: A study of quality dimensions. Paper read at the Second World Marketing Congress. University of Stirling, Stirling, Scotland.

Lovelock, C.H. 1983. 'Classifying services to gain strategic marketing insights.' Journal of Marketing. Vol. 47, Summer: 9-20.

Parasuraman, A. 1986. Marketing research. Reading. Massachusettes: Addison-Wesley.

Parasuraman, A., Zeithaml, V.A. \& Berry, L.L. 1988. 'SERVQUAL: A multiple-item scale for measuring consumer perceptions of service quality.' Journal of Retailing, Vol. 64, No. 1: $12-40$. 
Roberts, A.D. \& Kelley, E.J. 1985. 'Technoservices and the organizational encounter.' In Czepiel, J.A., Solomon, M.R. \& Surprenant, C.F. (eds.). The service encounter: Managing employeelcustomer interaction in service businesses. Lexington,
Massachusettes: Lexington Books: 283-290.

SAS institute, Inc. 1988. SAS/STAT TM User's Guide, Release 6.03 edition. Cary, North Carolina.

Thomas, D.R.E. 1978. 'Strategy is different in service business.' Harvard Business Review, Vol. 56, July-August: 158-165. 